\title{
Conflict between morphology and molecular data: a case of the genus Caryophyllaeus (Cestoda: Caryophyllidea), monozoic tapeworms of cyprinid fishes
}

\author{
Eva Bazsalovicsová ${ }^{1}$, Ivica Králová-Hromadová ${ }^{1}$, Jan Brabec ${ }^{2}$, Vladimíra Hanzelová ${ }^{1}$, Mikuláš Oros ${ }^{1}$ and \\ Tomáš Scholz ${ }^{2}$
}

\author{
${ }^{1}$ Institute of Parasitology, Slovak Academy of Sciences, Košice, Slovakia; \\ ${ }^{2}$ Institute of Parasitology, Biology Centre of the Academy of Sciences of the Czech Republic, České Budějovice, Czech Republic
}

\begin{abstract}
Molecular analysis of an extensive specimen collection of morphologically distinct tapeworms of the genus Caryophyllaeus Gmelin, 1790 (Cestoda: Caryophyllidea), parasites of cyprinid fishes in the Palaearctic Region, brought evidence of hostrelated plasticity in critical morphological characters widely used for species circumscription and classification of these tapeworms. The results obtained here do not support the traditionally used morphological concept of species-defining characters of the order Caryophyllidea Carus, 1863, especially due to high morphological plasticity of the scolex and the anterior end of the body. Several morphotypes within both Caryophyllaeus laticeps (Pallas, 1781) and Caryophyllaeus brachycollis Janiszewska, 1953 generally corresponding to different hosts and geographical regions, were recognised likely suggesting host- and geography-related intraspecific morphological variability. Genetic data confirmed euryxenous host specificity of both species, most profoundly C. laticeps, but did not support the existence of cryptic species. In fact, some of the fish hosts may harbour both of the congeneric species including several of their respective morphotypes. The pattern of morphological and genetic divergence observed in both cestode species studied indicates a scenario of possible host range extensions and subsequent parasite diversification. If molecular sequence variability and host-related morphological polymorphism are confirmed in other groups of monozoic cestodes, it may complicate species identification and straightforward classification of these parasites.
\end{abstract}

Keywords: scolex morphology, morphological plasticity, Caryophyllaeus laticeps, Caryophyllaeus brachycollis, mitochondrial haplotypes, cox1, 1srDNA, morphotypes

Classification, taxonomy and species identification of parasites have been largely, if not exclusively, based on morphological characteristics. Monozoic fish cestodes of the order Caryophyllidea Carus, 1863 seem to represent the most basal group of 'true' tapeworms (Eucestoda) (Olson et al. 2001, Waeschenbach et al. 2012, Caira et al. 2014). Subtle differences in shape and size of the scolex and the anteriormost extent of vitelline follicles and testes play the central role in species identification of some groups of caryophylideans (Dubinina 1987, Oros et al. 2010, Scholz et al. 2011).

As part of a large-scale survey of monozoic tapeworms parasitising cyprinids, we collected an extensive material of Caryophyllaeus laticeps (Pallas, 1781) from a wide spectrum of cyprinid fishes throughout Europe and processed it using the standardised methodology (Oros et al. $2009,2010)$. In addition, samples of a less frequently found congeneric species, Caryophyllaeus brachycollis Janisze- wska, 1953, were also included into present study. Within the populations of these tapeworms we found several morphotypes, often specific to different fish hosts, some of which were supposed to represent new species, e.g. specimens from Chondrostoma Agassiz and Vimba Fitzinger.

Sequences of two genes (partial mitochondrial cytochrome $c$ oxidase subunit I - coxl, and partial large subunit of the ribosomal DNA - 1srDNA), which were successfully used in previous phylogenetic studies on caryophyllideans (Bazsalovicsová et al. 2011, Scholz et al. 2011, Brabec et al. 2012), were obtained to assess the relationships among the individual $C$. laticeps and C. brachycollis morphotypes from different hosts and regions. The results of molecular analysis were confronted with main morphological discriminative characters of individual morphotypes. The reliability of the traditional morphological criteria for caryophyllidean species circumscription and systematics is also discussed.

Address for correspondence: I. Králová-Hromadová, Institute of Parasitology, Slovak Academy of Sciences, Hlinkova 3, Košice, Slovakia. Phone: 421556334455; Fax: 421556331414; E-mail: hromadova@saske.sk 


\section{MATERIALS AND METHODS}

\section{Parasites}

Table 1 summarises details on Caryophyllaeus laticeps and C. brachycollis specimens analysed in the present work. Tapeworms studied were obtained by dissection of freshly killed fish; they were divided into three parts: the anterior part with the scolex and the posterior part with terminal genitalia were fixed with hot $4 \%$ formalin for morphological studies, whereas the middle part was fixed in molecular-graded ethanol (95-99\%) for DNA analyses. All specimens studied could be assigned to one of seven morphotypes, distinguished mainly by the shape of the body, scolex and neck, and position of the anteriormost testes and vitelline follicles (Table 2). A detailed morphological characterisation of all morphotypes along with redescription of $C$. laticeps and $C$. brachycollis will be presented in separate papers.

\section{DNA isolation, PCR amplification, sequencing}

Genomic DNA was isolated using the QIAamp ${ }^{\circledR}$ DNA Kit (QIAGEN, Hilden, Germany). For PCR amplification, a total volume of amplification mixture was $20 \mu \mathrm{l}$ and contained 10-20 ng of genomic DNA, 20 pmol of each of the forward and reverse primers, $0.2 \mathrm{mM}$ of each of the deoxynucleotide triphosphate (Fermentas UAB, Vilnius, Lithuania), $0.5 \mathrm{U}$ of Taq

Table 1. List of Caryophyllaeus specimens (code, host, locality) and genes (mitochondrial coxl; nuclear lsrDNA) analysed.

\begin{tabular}{|c|c|c|c|c|c|c|c|c|}
\hline $\begin{array}{l}\text { Sample } \\
\text { code }^{1}\end{array}$ & Fish host & $\begin{array}{l}\text { Country } \\
\text { of origin }\end{array}$ & Locality & $\begin{array}{l}\operatorname{cox} 1 \\
\text { Acc. No. }\end{array}$ & $\begin{array}{l}\text { coxl } \\
\text { haplotype }\end{array}$ & $\begin{array}{l}\text { lsrDNA } \\
\text { Acc. No. }\end{array}$ & Cestode species & Morphotype \\
\hline SK-SC-1 & Squalius cephalus & Slovakia & Myslava Stream & KF051109 & Hal & KF051154 & C. brachycollis & C.b. morphotype 1 \\
\hline SK-SC-2 & S. cephalus & Slovakia & Myslava Stream & KF051110 & & KF051138 & C. brachycollis & C.b. morphotype 1 \\
\hline SK-SC-3 & S. cephalus & Slovakia & Myslava Stream & KF051111 & Ha1 & KF051155 & C. brachycollis & C.b. morphotype 1 \\
\hline SK-SC-4 & S. cephalus & Slovakia & Myslava Stream & KF051105 & Ha1 & KF051156 & C. brachycollis & C.b. morphotype 1 \\
\hline SK-SC-5 & S. cephalus & Slovakia & Myslava Stream & KF051112 & Ha1 & KF051140 & C. brachycollis & C.b. morphotype 1 \\
\hline SK-SC-6 & S. cephalus & Slovakia & Myslava Stream & KF051113 & Ha1 & KF051157 & C. brachycollis & C.b. morphotype 1 \\
\hline SK-SC-7 & S. cephalus & Slovakia & Myslava Stream & KF051106 & Ha1 & KF051158 & C. brachycollis & C.b. morphotype 1 \\
\hline SK-BS-1 & Ballerus sapa & Slovakia & Danube River & KF051114 & $\mathrm{Ha} 2$ & KF051159 & C. laticeps & C.l. morphotype 1 \\
\hline SK-BS-2 & B. sapa & Slovakia & Danube River & KF051115 & $\mathrm{Ha} 2$ & KF051160 & C. laticeps & C.l. morphotype 1 \\
\hline SK-BS-3 & B. sapa & Slovakia & Danube River & KF051117 & $\mathrm{Ha} 2$ & KF051162 & C. laticeps & C.l. morphotype 1 \\
\hline SK-BS-4 & B. sapa & Slovakia & Danube River & KF051118 & $\mathrm{Ha} 2$ & KF051163 & C. laticeps & C.l. morphotype 1 \\
\hline SK-AB-1 & Abramis brama & Slovakia & Latorica River & KF051121 & $\mathrm{Ha} 3$ & 1166 & C. brachycollis & C.b. morphotype 2 \\
\hline SK-BB-1 & Ballerus ballerus & Slovakia & Latorica River & KF051122 & $\mathrm{Ha} 4$ & KF051167 & C. brachycollis & C.b. morphotype 2 \\
\hline SK-AB-2 & A. brama & Slovakia & Latorica River & KF051123 & $\mathrm{Ha} 5$ & KF051139 & C. brachycollis & C.b. morphotype 2 \\
\hline SK-AB-3 & A. brama & lovakia & Tisa River & KF051100 & & & C. brachycollis & C.b. morphotype 2 \\
\hline SK-AB-4 & A. brama & Slovakia & Danube River & KF051131 & & & C. laticeps & C.l. mo \\
\hline BG-VM-1 & Vimba melanops & Bulgaria & Arda River & KF051107 & $\mathrm{Ha} 8$ & KF051142 & C. laticeps & C.l. morphotype 2 \\
\hline BG-VM-2 & $V$. melanops & Bulgaria & Arda River & KF051108 & & & C. laticeps & C.l. morphotype 2 \\
\hline BG-VM-3 & $V$. melanops & Bulgaria & & & & & C. laticeps & C.l. morphotype 2 \\
\hline BG-VM-4 & $V$. melanops & Bulgaria & Arda River & KF051092 & Ha10 & KF051145 & C. laticeps & C.l. morphotype 2 \\
\hline BG-VM-5 & $V$. melanops & Bulgaria & Arda River & KF0 & & 146 & C. laticeps & C.l. morphotype 2 \\
\hline BG-VM-6 & $V$. melanops & Bulgaria & & & & & C. laticeps & C.l. morphotype 2 \\
\hline BG-VM-7 & $V$. melanops & Bulgaria & Arda River & $\mathrm{KF} 0$ & 2 & 47 & C. laticeps & C.l. morphotype 2 \\
\hline BG-VM-8 & $V$. melanops & Bulgaria & Arda River & KF0 & Ha12 & $\mathrm{KF}$ & C. laticeps & C.l. morphotype 2 \\
\hline BG-VM-9 & $V$. melanops & Bulgaria & Arda River & & Ha12 & 1149 & C. laticeps & C.l. morphotype 2 \\
\hline BG-VM-10 & $V$. melanops & Bulgaria & Arda River & KF0S & & 1150 & C. laticeps & C.l. morphotype 2 \\
\hline BG-VM-11 & $V$. melanops & Bulgaria & Arda River & KF0 & Ha12 & 51 & C. laticeps & C.l. morphotype 2 \\
\hline BG-VM-12 & $V$. melanops & Bulgaria & Arda River & KF051098 & $\mathrm{Ha} 8$ & 1152 & C. laticeps & C.l. morphotype 2 \\
\hline BG-VM-13 & $V$. melanops & Bulgaria & Arda River & KF051099 & & KF051153 & C. laticeps & C.l. morphotype 2 \\
\hline BG-BC-1 & Barbus cyclolepis & Bulgaria & Arda River & $\mathrm{KFC}$ & Ha1 & 70 & C. brachycollis & C.b. morphotype 1 \\
\hline RU-AB-1 & A. brama & Russia & Volga River & KF051126 & Ha13 & 1176 & C. laticeps & C.l. morphotype 1 \\
\hline RU-AB-2 & A. brama & Russia & Volga River & KF051127 & & & C. laticeps & C.l. morphotype 1 \\
\hline RU-BS-1 & B. sapa & Russia & Volga River & KF051132 & & KF051173 & C. laticeps & C.l. morphotype 1 \\
\hline RU-BB-1 & Blicca bjoerkna & Russia & Volga River & KF051133 & Ha16 & KF051174 & C. brachycollis & C.b. morphotype 2 \\
\hline RU-AB-3 & A. brama & Russia & Rybinsk WR & KF051134 & & & C. brachycollis & C.b. morphotype 2 \\
\hline AT-CN-1 & Chondrostoma nasus & Austria & Drau River & KF051128 & Ha18 & KF051176 & C. laticeps & C.l. morphotype 4 \\
\hline AT-CN-2 & C. nasus & Austria & Drau River & KF051129 & Ha19 & KF051179 & C. laticeps & C.l. morphotype 4 \\
\hline AT-CN-3 & C. nasus & Austria & Drau River & KF051130 & $\mathrm{Ha} 20$ & KF051180 & C. laticeps & C.l. morphotype 4 \\
\hline FR-BM-1 & Barbus meridionalis & France & Cassole River & KF051135 & Ha21 & KF051137 & C. brachycollis & C.b. morphotype 1 \\
\hline FR-BB-1 & Barbus barbus & France & Arges River & KF051136 & $\mathrm{Ha} 22$ & KF051181 & C. brachycollis & C.b. morphotype 1 \\
\hline SK-BM-1 & B. meridionalis & Slovakia & Myslava Stream & JQ034064² & $\mathrm{Ha} 23$ & JQ034120² & C. brachycollis & C.b. morphotype 1 \\
\hline SK-AB-5 & A. brama & Slovakia & Tisa River & JQ034078-832 & Нa24-26 & JQ034124² & C. brachycollis & C.b. morphotype 2 \\
\hline SK-BS-5 & B. sapa & Slovakia & Latorica River & $\mathrm{JQ} 034077^{2}$ & $\mathrm{Ha} 27$ & JQ034122² & C. laticeps & C.l. morphotype 5 \\
\hline SK-AB-6 & A. brama & Slovakia & Tisa River & JQ034070-712 & На28-29 & JQ034123² & C. laticeps & C.l. morphotype 5 \\
\hline SK-CC-1 & Cyprinus carpio & Slovakia & Tisa River & JQ034066-68² & На30-32 & JQ0341212 & C. laticeps & C.l. morphotype 3 \\
\hline
\end{tabular}

Abbreviations: C.b. - Caryophyllaeus brachycollis; C.l. - Caryophyllaeus laticeps; WR - water reservoir; ${ }^{1}$ sample codes comprise international country code-initials of host-sample number; ${ }^{2}$ sequences published by Brabec et al. (2012). 
Bazsalovicsová et al.: Conflict between morphological and molecular data

Table 2. Main distinguishable features among morphotypes of Caryophyllaeus laticeps (CL) and Caryophyllaeus brachycollis (CB).

\begin{tabular}{|c|c|c|c|c|c|c|}
\hline Morphotype & Fish host (genera) & Body & Scolex shape & Neck & First testes & Vitelline follicles (VF) \\
\hline CL $1^{1}$ & Abramis, Ballerus & slender & flabellate to spatulate & long, slender & posterior to $\mathrm{VF}$ & small, reach to ovary \\
\hline CL 2 & Vimba & robust & spatulate & short, wide & close to VF & anterior to gonopore \\
\hline CL 3 & Cyprinus & slender & cuneicrispitate & widened anteriorly & posterior to VF & small, reach to ovary \\
\hline CL 4 & Chondrostoma & large, robust & spatulate & long, wide & posterior to $\mathrm{VF}$ & small, reach to ovary \\
\hline CL 5 & Abramis, Ballerus & slender & flabellate & moderate & posterior to $\mathrm{VF}$ & large, anterior to gonopore \\
\hline $\mathrm{CB} 1^{2}$ & Barbus, Squalius & robust & flabellate & short, wide & same level as VF & small, reach to ovary \\
\hline CB 2 & Abramis, Ballerus, Blicca & slender & flabellate to spatulate & moderate & posterior to $\mathrm{VF}$ & small, reach to ovary \\
\hline
\end{tabular}

'considered to be a 'nominotypical' morphotype described as Taenia laticeps by Pallas (1781) and redescribed by Fuhrmann (1931); ${ }^{2}$ considered to be a 'nominotypical' morphotype described by Janiszewska (1953).

DNA polymerase (Invitrogen, Carlsbad, CA, USA) with corresponding reaction buffer and $1.5 \mathrm{mM} \mathrm{MgCl}_{2}$. The PCR amplifications were run as follows: $5 \mathrm{~min}$ at $94^{\circ} \mathrm{C}$ as an initial step; then 30 cycles of $1 \mathrm{~min}$ at $94^{\circ} \mathrm{C}, 1 \mathrm{~min}$ at $55^{\circ} \mathrm{C}$, and $2 \mathrm{~min}$ at $72{ }^{\circ} \mathrm{C}$. The final step was $10 \mathrm{~min}$ at $72^{\circ} \mathrm{C}$. The PCR products were loaded on the $1 \%$ agarose gel and purified either using the Wizard PCR purification Kit (Promega, Madison, WI, USA) or with exonuclease I and shrimp alkaline phosphatase (Werle et al. 1994). Sequencing was performed using automatic genetic analyser Applied Biosystems 3130x1 (Applied Biosystems, Foster City, California, USA) and BigDye Terminator v3.1 Cycle sequencing kit (Applied Biosystems).

For amplification and sequencing of the partial coxl gene, the primers CFCYT2 and CRCYT2, specifically designed for caryophyllidean cestodes by Bazsalovicsová et al. (2011), were used. They amplified $657 \mathrm{bp}$ (219 amino acids) of the coxl gene, including the start codon, which was determined according to the echinoderm mitochondrial code (Telford et al. 2000).

Partial lsrDNA gene (domains D1-D3) was amplified using the LSU5 and 1500R primers originally described in Olson et al. (2003). The length of the amplified D1-D3 1srDNA region in Caryophyllaeus specimens varied from 1576 to $1623 \mathrm{bp}$. The amplified products were sequenced using two amplification primers together with four internal primers $300 \mathrm{~F}, 400 \mathrm{R}$, 900F and ECD2 (Olson et al. 2003). Nucleotide sequence data originally reported in this paper are available in the GenBank ${ }^{\mathrm{TM}}$, EMBL and DDBJ databases (see Table 1 for accession numbers).

\section{Phylogenetic analyses}

Contiguous sequences were assembled and inspected for errors using Geneious (Geneious version 6.0.5 created by Biomatters; available from http:/www.geneious.com/). Alignments were created using the E-INS-i algorithm of the program MAFFT (Katoh and Standley 2013) and ambiguously aligned positions were manually excluded from the lsrDNA alignment thus creating a $1578 \mathrm{bp}$ long data set. Interrelationships among Caryophyllaeus species were evaluated by analysing the D1-D3 1srDNA and coxl data parts as a concatenated data set by maximum likelihood (ML) and Bayesian inference (BI) methods. Best ML estimate resulted from $10 \mathrm{ML}$ searches in the program Garli ver. 2.0 (Zwickl 2006), employing partitioned scheme $\left(\right.$ lsrDNA) $\left(\operatorname{coxl} 1^{\text {st }}\right)\left(\operatorname{cox} 12^{\text {nd }}\right)\left(\operatorname{cox} 13^{\text {rd }}\right)$ and models $(\mathrm{HKY}+\mathrm{I})$ $(\operatorname{TrN}+\mathrm{I})(\mathrm{F} 81+\mathrm{G})(\mathrm{TrN}+\mathrm{G})$ chosen according to the BIC criterion in PartitionFinder 1.1.0 (Lanfear et al. 2012). ML nodal support was computed by running 5 searches on each of the 500 bootstrap resamples in Garli.

BI trees were constructed using MrBayes ver. 3.2 (Ronquist et al. 2012), running 4 independent MCMCMC runs of 4 chains for 8 million generations and sampling tree topologies every $1000^{\text {th }}$ generation. Analogously to ML analyses, the (lsrDNA) $\left(\operatorname{cox} 11^{\text {st }}, \operatorname{cox} 12^{\text {nd }}\right)\left(\operatorname{cox} 13^{\text {rd }}\right)$ partitioning scheme and $(\mathrm{HKY}+\mathrm{I})$ $(\mathrm{HKY}+\mathrm{G})(\mathrm{GTR}+\mathrm{G})$ model were chosen and employed. Burnin period was set to 2.5 million generations according to the standard deviation of split frequencies values $(<0.01)$ and by checking for MCMC convergence using AWTY (Nylander et al. 2008).

\section{RESULTS}

\section{Structure and variation of coxl and IsrDNA}

In total, 32 different cox 1 haplotypes (Ha) were determined in all specimens of Caryophyllaeus Gmelin, 1790 analysed. Out of them, 13 and $19 \mathrm{Ha}$ were found exclusively in $C$. brachycollis (Ha1, 3-6, 16, 17, 21-26) and $C$. laticeps (Ha2, 7-15, 18-20, 27-32), respectively (Table 1). In the C. laticeps clade, each host and/or geographic population was characterised by specific cox 1 haplotype/haplotypes, none of which was shared among populations.

The specimens from the Danube River (Slovakia) from white-eye bream Ballerus sapa (Pallas) possessed only single cox 1 haplotype (Table $1, \mathrm{Ha} 2$ ), whereas the remaining $C$. laticeps tapeworms from Bulgaria (Arda River), Russia (Volga River) and Austria (Drau River) were characterised by multiple haplotypes and pairwise sequence divergence among their individuals ranged between $0-0.9 \%, 0.2 \%$ and $0.5-0.6 \%$, respectively. The overall intraspecific cox 1 sequence differences of $C$. laticeps ranged between $0.2 \%$ and $16.9 \%$.

A very similar situation was observed in C. brachycollis. Each host/geographic population was characterised by specific haplotype/haplotypes with just one exception: Hal was detected, in addition to a homogeneous population of C. brachycollis from chub Squalius cephalus (Linnaeus) in Slovakia (Myslava Stream), also in a specimen from Bulgaria from barbel Barbus cyclolepis Heckel (Arda River) (Table 1).

Nucleotide sequence comparison of D1-D3 lsrDNA revealed $0.1-3.1 \%$ sequence divergence between both Caryophyllaeus species. Intraspecific sequence differences were $0-0.4 \%$ in $C$. laticeps and $0-0.5 \%$ in $C$. brachycollis. 


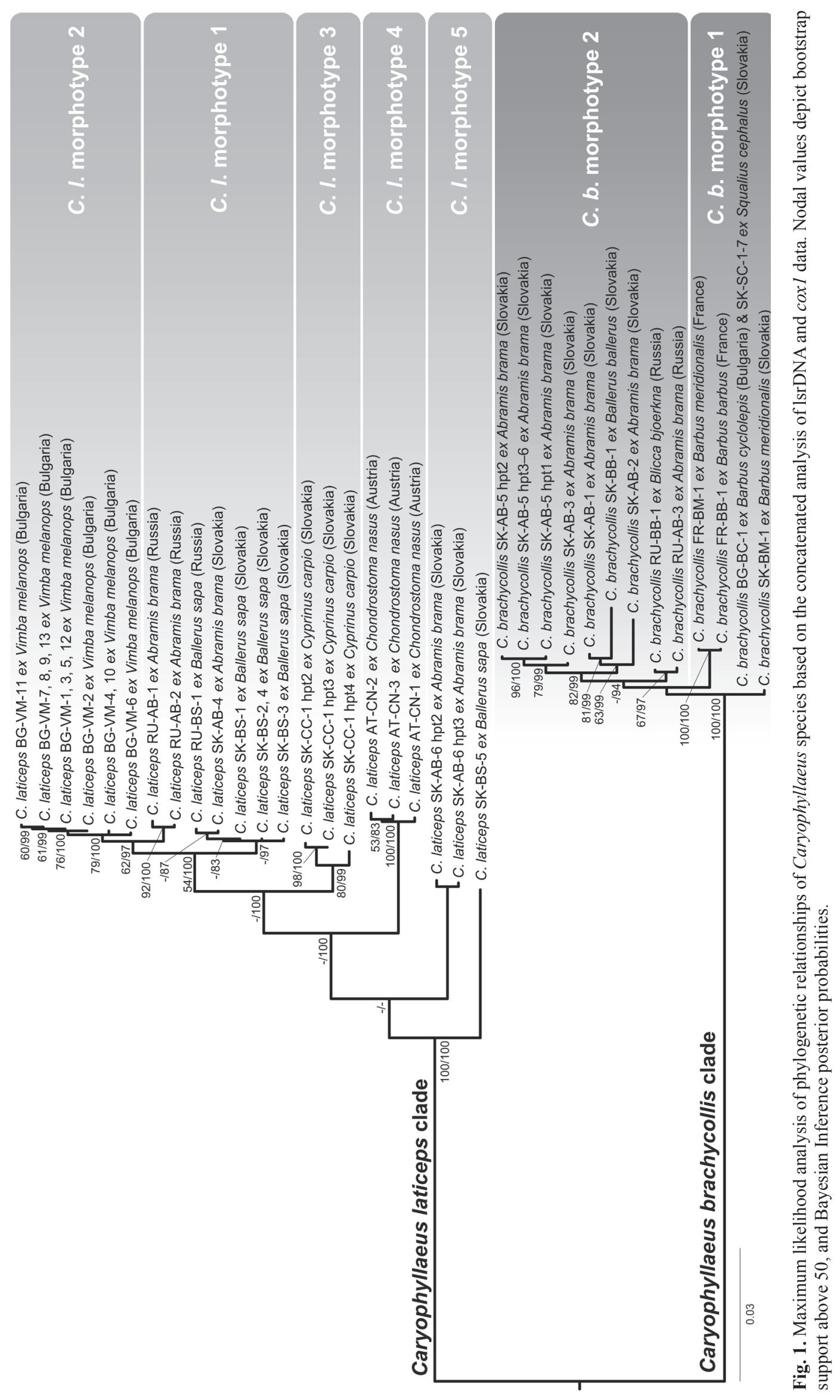




\section{Phylogenetic relationships}

Sequence analyses of Caryophyllaeus specimens (Fig. 1) agreed on a single phylogenetic scenario: the existence of two statistically well-supported Caryophyllaeus clades that correspond to the two historically established congeneric species, C. laticeps and C. brachycollis. Each of these two clades further divided into several monophyletic lineages that receive weaker statistical supports, but generally not contradict the morphotype groups as revealed by the current morphological re-evaluation (Table 2). Therefore, the majority of the morphotypes of C. laticeps $(2,3,4$ and 5) can be viewed as cohesive genetic clusters that are correlated first with geography and nested within that, occasionally with a particular host.

In contrast, $C$. brachycollis morphotype 1 and $C$. laticeps morphotypes 1 and 5 belong to those groupings not found on the resulting phylogram as monophyletic lineages. However, the branching pattern that separates the unrelated lineages of both $C$. brachycollis morphotype 1 and $C$. laticeps morphotype 1 representatives, respectively, does not receive any statistical support in either of the cases, which also means that the monophyly of C. brachycollis and $C$. laticeps morphotypes 1 may not be expelled on the basis of the present data.

A slightly different situation can be observed with C. laticeps morphotype 5. Again, the split of these tapeworms into two evolutionary distinct lineages is not statistically supported, but both of these lineages form relatively long branches, a situation not found elsewhere on the tree. The remaining C. laticeps morphotypes parasitising species of the genera Vimba Fitzinger, Cyprinus Linnaeus and Chondrostoma Agassiz (morphotypes 2-4) reflect the definitive hosts and geographical distribution of possibly subpopulations of this tapeworm species.

\section{DISCUSSION}

The present study brings a DNA-based evidence of host-related plasticity of morphological characters currently employed to circumscribe and classify species of monozoic fish tapeworms. The results obtained here suggest that delimiting species of Caryophyllaeus using solely morphological characteristics may be misleading. Morphology of the scolex plays the key role in identification of caryophyllidean species, being quite diverse (Mackiewicz 1972, Oros et al. 2010, Scholz et al. 2011, Ash et al. 2012). However, molecular markers do not provide convincing evidence that the morphotypes of both Caryophyllaeus congeners from different fish hosts and geographical regions with markedly different scolex morphology represent individual species. Genetic data support the conclusion of euryxenous host specificity of both species, especially of the geographically widely distributed C. laticeps, and do not confirm the existence of cryptic species. In fact, several of the definitive hosts may harbour simultaneously both of the congeneric species and sev- eral of their respective morphotypes, such as freshwater bream infected with $C$. laticeps as well as $C$. brachycollis (Fig. 1). The co-existence of divergent parasite lineages in the same fish host and the higher that previously expected species diversity in freshwater bream indicate that some factors related to transmission of developmental stages of parasites may play a key role. Blasco-Costa et al. (2010), who observed a similar phenomenon in haploporid trematodes in sympatric mullets in the Mediterranean, present two hypotheses on the action of factors linked to the effect of the enhanced encounter of larval stages from molluscs with the definitive hosts.

Genetic markers represent a powerful tool for studies on intraspecific variability and made it possible to unravel cryptic species (genetically distinct but morphologically very similar species) in many taxonomic groups, including helminths (Nadler and Peréz-Ponce de León 2011). However, morphology still has, and undoubtedly always will play, a key role in species circumscription and a higher-level classification, even though the importance of individual morphological characteristics, which have been previously used as differential criteria, may change. In the present study, morphologically well-defined populations of Caryophyllaeus species from different hosts appeared to represent only different morphotypes of presumably polymorphic species with a wide spectrum of definitive hosts.

It is evident that morphology alone may not yield adequate taxonomic resolution and can provide misleading answers to basic questions about parasite diversity and host-parasite relationships (Nadler and Peréz-Ponce de León 2011). The advent of molecular systematics brought new characters for circumscribing parasite species in nature, addressing concerns that morphology alone may be insufficient to identify all species unequivocally, and providing further advantages for studying parasite systematics and evolution (Nadler 1990, McManus and Bowles 1996).

Even though discovery of cryptic species has been a more frequently found scenario in parasitology, there are cases where the exact opposite occurred, e.g. when putatively separate species showed very high levels of molecular similarity, thus indicating conspecificity. This was the case of Ostertagia Ransom, 1907 nematodes of reindeer in Scandinavia (Dallas et al. 2000) and Lamellodiscus Johnston et Tiegs, 1922 monogeneans of sparid fishes in the Mediterranean (Desdevises et al. 2000). In such cases, molecular tools may contribute to a better understanding of biodiversity and parasites' phenotypic plasticity, including host-induced morphological changes. High phenotypic plasticity of Siphomutabilus Miller et Cribb, 2013 digeneans from Indo-Pacific caesionines represents another example where DNA sequence data are able to reveal relationships not easily recognised from morphology alone (Miller and Cribb 2013).

The disagreement between morphological and molecular data is apparently the case of some representatives of the order Caryophyllidea, where conflict between mor- 
phological and genetic data represents one of the most important problems in their taxonomy and systematics. This problem was faced for the first time in the caryophyllidean genus Khawia Hsü, 1935 (family Lytocestidae). Type species of the genus, Khawia sinensis Hsü, 1935, which is a specific, widely distributed parasite of carp (Cyprinus carpio Linnaeus - Cyprininae), and $K$. saurogobii $\mathrm{Xi}$, Oros, Wang, Wu, Gao et Nie, 2009, a parasite of gudgeons (Saurogobio spp. - Gobioninae) known from a relatively small area in China, were found to be morphologically clearly different species (Xi et al. 2009, Scholz et al. 2011). However, they are almost indistinguishable in their ribosomal internal transcribed spacer 2 (ITS2), ssrDNA, lsrDNA, and mitochondrial coxl and nicotinamide dehydrogenase subunit III ( ad3) sequences (Scholz et al. 2011, Králová-Hromadová et al. 2012). It was assumed that $K$. saurogobii, after switching to a new, unrelated fish host, may have undergone morphological divergence as a result of ongoing sympatric speciation, but this process has not been accompanied by corresponding nucleotide changes in the standard genes used as informative markers in our analyses (Scholz et al. 2011).

In contrast to $K$. saurogobii, $C$. laticeps has a very large distribution area, which involves Europe, spanning in north-southern direction from Sweden (Chubb 1982) towards Turkey, and in west-eastern direction from Britain towards Russia (Protasova et al. 1990). High morphological plasticity of different host populations of this species probably reflects the effect of individual fish hosts and, possibly, their geographical origin. The present molecular data provide strong support to consider $C$. laticeps as a euryxenous parasite of a wide spectrum of fishes of different genera and subfamilies, i.e. cyprinid fishes of the subfamilies Leuciscinae, such as freshwater bream Abramis brama (Linnaeus), zope Ballerus ballerus (Linnaeus), white-eye bream Ballerus sapa, white bream Blicca bjoerkna (Linnaeus), vimba bream Vimba vimba (Linnaeus), roach Rutilus rutilus (Linnaeus), common nase Chondrostoma nasus (Linnaeus), and Cyprininae, such as crucian carp Carassius carassius (Linnaeus), common carp Cyprinus carpio (Protasova et al. 1990, Oros and Hanzelová 2009). Such an extraordinarily wide range of definitive fish hosts of $C$. laticeps may stand behind its phenotypic plasticity.

The pattern of morphological and genetic divergence, observed in both cestode species studied, is mostly concordant, with some exceptions involving paraphyly. It may indicate a scenario of possible host range extensions (colonisations) by the parasites within a particular geographical area and subsequent diversification. The limited data set did not allow us to determine an ancestral host, but the host associations of Caryophyllaeus suggest that the abramine lineage seems to be an important host group.

Another species of the genus, C. fimbriceps Annenkova-Chlopina, 1919 from common carp C. carpio, was differentiated from $C$. brachycollis and C. laticeps mainly by its scolex morphology, anterior extent of vitelline follicles and large size of cirrus-sac (see Dubinina 1987, Scholz 1989, Protasova et al. 1990). As evidenced by the present study, Caryophyllaeus tapeworms from common carp were conspecific with $C$. laticeps and represent the morphotype 3 of this species. They have a wide scolex similar to $C$. fimbriceps, but their cirrus-sac is small and vas deferens is not surrounded by vitelline follicles on the ventral and dorsal side. Therefore, taxonomic status and validity of $C$. fimbriceps, which was previously often reported as a pathogenic parasite of common carp in fishponds of eastern Europe and the former Soviet Union (Bauer et al. 1973), have to be critically reviewed.

Caryophyllideans are generally known to have very specific morphological characteristics (monozoic body with only one set of reproductive organs) and also exceptional molecular and genetic features, such as ribosomal ITS paralogues, polyploidy, multiple ribosomal loci and NUMTs (nuclear copies of mitochondrial DNA) (Králová-Hromadová et al. 2010, 2012, Orosová et al. 2010, Bazsalovicsová et al. 2011, 2012, Brabec et al. 2012). However, the phenomenon of NUMTs, as described by Brabec et al. (2012) in Slovak C. laticeps individuals from freshwater bream $A$. brama and common carp Cyprinus carpio, and Slovak $C$. brachycollis specimen from freshwater bream A. brama (see Fig. 1), was not noticed in any specimens analysed in the present study.

As indicated by this study and based on evaluation of numerous materials, several genera of caryophyllidean tapeworms are pending revision, which should include morphological and genetic evaluation of well-fixed fresh materials from different hosts and geographical regions. Based on our previous experience with this cestode group, it is evident that combined methodological approach needs to be applied in their systematic studies. Molecular taxonomy alone is definitely not a panacea for resolving the systematics of caryophyllideans, but in combination with morphology-based taxonomy, it is a suitable tool for a better understanding of their diversity.

Acknowledgements. The authors are grateful to the following colleagues for help of collection of Caryophyllaeus cestodes or for providing some specimens: Anirban Ash (India), Franz Jirsa (Austria), Diana Kirin (Bulgaria), Larisa Poddubnaya (Russia), Andrea Šimková and Martina Dávidová (Czech Republic). Helpful suggestions of two anonymous reviewers are also much appreciated. This work was supported by the Slovak Research and Development Agency under contract APVV-0653-11, project of the Grant Agency of the Slovak Republic (VEGA 2/0129/12), project 'Centre of Excellence for Parasitology' (Code ITMS: 26220120022), based on the support of Operational Programme 'Research \& Development' funded from the European Regional Development Fund (rate 0.1). Financial support of the Czech Science Foundation (project No. 505/12/G112) and the Institute of Parasitology (RVO: 60077344) is also acknowledged. 
Ash A., Scholz T., de Chambier A., Brabec J., Oros M., Kar P.K., Chavan S.P., Mariaux J. 2012: Revision of Gangesia (Cestoda: Proteocephalidea) in the Indomalayan region: morphology, molecules and surface ultrastructure. PLoS ONE 7: e46421.

Bauer O.N., Musselius V.A., Strelkov Y.A. 1973: Diseases of Pond Fishes. Israel Programme for Scientific Translations, Jerusalem, $220 \mathrm{pp}$.

Bazsalovicsová E., Králová-Hromadová I., Štefka J., Scholz T. 2012: Molecular characterization of Atractolytocestus sagittatus (Cestoda: Caryophyllidea), monozoic parasite of common carp, and its differentiation from the invasive species Atractolytocestus huronensis. Parasitol. Res. 110: 1621-1629.

Bazsalovicsová E., Králová-Hromadová I., Štefka J., Scholz T., Hanzelová V., Vavrová S., Szemes T., Kirk R. 2011: Population study of Atractolytocestus huronensis (Cestoda: Caryophyllidea), an invasive parasite of common carp introduced to Europe: mitochondrial coxl haplotypes and intragenomic ribosomal ITS2 variants. Parasitol. Res. 109: 125-131.

Blasco-Costa I., Balbuena J.A., Raga J.A., Kostadinova A., OLson P.D. 2010: Molecules and morphology reveal cryptic variation among digeneans infecting sympatric mullets in the Mediterranean. Parasitology 137: 287-302.

Brabec J., Scholz T., Králová-Hromadová I., BazsalovicSOvÁ E., Olson P.D. 2012: Substitution saturation and nuclear paralogs of commonly employed phylogenetic markers in the Caryophyllidea, an unusual group of non-segmented tapeworms (Platyhelminthes). Int. J. Parasitol. 42: 259-267.

Caira J.N., Jensen K., Waeschenbach A., Olson P.D., LitTLEWOOD T.D. 2014: Orders out of chaos - molecular phylogenetics reveals the complexity of shark and stingray tapeworm relationships. Int. J. Parasitol. 44: 55-73.

Chubв J.C. 1982: Seasonal occurrence of helminths in freshwater fishes. Part IV. Adult Cestoda, Nematoda and Acanthocephala. Adv. Parasitol. 20: 1-292.

Dallas J.F., Irvine R.J., Halvorsen O. 2000: DNA evidence that Ostertagia gruehneri and Ostertagia arctica (Nematoda: Ostertagiinae) in reindeer from Norway and Svalbard are conspecific. Int. J. Parasitol. 30: 655-658.

Desdevises Y., Jovelin R., Jousson O., Morand S. 2000: Comparison of ribosomal DNA sequences of Lamellodiscus spp. (Monogenea, Diplectanidae) parasitising Pagellus (Sparidae, Teleostei) in the north Mediterranean Sea: species divergence and coevolutionary interactions. Int. J. Parasitol. 30: 741-746.

Dubinina M.N. 1987: [Class tapeworms - Cestoda Rudolphi,1808.] In: O.N. Bauer (Ed.), [Key to the Parasites of Freshwater Fishes of the USSR.], Nauka, Leningrad, pp. 5-76. (In Russian.)

Fuhrmann O. 1931: Dritte Klasse des Cladus Plathelminthes. Cestoidea. In Kükenthal's Handbuch der Zoologie, W. Kükenthal and T. Krumbach (Eds.). Walter de Gruyter \& Co., Berlin and Leipzig, pp. 141-416.

JANISZEWSKA J. 1953: Caryophyllaeus brachycollis n. sp. z ryb karpiowatych. Zoologica Poloniae 6: 57-68.

Katoh K., Standley D.M. 2013: MAFFT Multiple Sequence Alignment Software Version 7: Improvements in performance and usability. Mol. Biol. Evol. 30: 772-780.

Králová-Hromadová I., Bazsalovicsová E., Oros M., Scholz T. 2012: Sequence structure and intragenomic vari- ability of ribosomal ITS2 in monozoic tapeworms of the genus Khawia (Cestoda: Caryophyllidea), parasites of cyprinid fish. Parasitol. Res. 111: 1621-1627.

Králová-Hromadová I., ŠtefKa J., Špakulová M., Orosová M., Bombarová M., Hanzelová V., Bazsalovicsová E., Scholz T. 2010: Intraindividual ITS1 and ITS2 ribosomal sequence variation linked with multiple rDNA loci: a case of triploid Atractolytocestus huronensis, the monozoic cestode of common carp. Int. J. Parasitol. 40: 175-181.

Lanfear R., Calcott B., Ho S.Y.W., Guindon S. 2012: Partition Finder: combined selection of partitioning schemes and substitution models for phylogenetic analyses. Mol. Biol. Evol. 29: $1695-1701$.

Mackiewicz J.S. 1972: Caryophyllidea (Cestoidea): a review. Exp. Parasitol. 31: 417-512.

McManus D.P., Bowles J. 1996: Molecular genetic approaches to parasite identification: their value in diagnostic parasitology and systematics. Int. J. Parasitol. 26: 687-704.

Miller T.L., CribB T.H. 2013: Dramatic phenotypic plasticity within species of Siphomutabilus n. g. (Digenea: Cryptogonimidae) from Indo-Pacific caesionines (Perciformes: Lutjanidae). Syst. Parasitol. 86: 101-112.

NADLER S.A. 1990: Molecular approaches to studying helminth population genetics and phylogeny. Int. J. Parasitol. 20: 1-29.

Nadler S.A., Peréz-Ponce de León G. 2011: Integrating molecular and morphological approaches for characterizing parasite cryptic species: implications for parasitology. Parasitology 138: $1688-1709$.

Nylander J.A., Wilgenbusch J.C., Warren D.L., Swofford D.L. 2008: AWTY (are we there yet?): a system for graphical exploration of MCMC convergence in Bayesian phylogenetic. Bioinformatics 24: 581-583.

Olson P.D., Cribb T.H., Tkach V.V., Bray R.A., Littlewood D.T.J. 2003: Phylogeny and classification of the Digenea (Platyhelminthes: Trematoda). Int. J. Parasitol. 33: 733-755.

Olson P.D., Littlewood D.T.J., Bray R.A., Mariaux J. 2001: Interrelationships and evolution of the tapeworms (Platyhelminthes: Cestoda). Mol. Phylogenet. Evol. 19: 443-467.

Oros M., Hanzeloví V. 2009: Re-establishment of the fish parasite fauna in the Tisa River system (Slovakia) after a catastrophic pollution event. Parasitol. Res. 104: 1497-1506.

Oros M., Hanzelová V., Scholz T. 2009: Tapeworm Khawia sinensis: review of the introduction and subsequent decline of a pathogen of carp, Cyprinus carpio. Vet. Parasitol. 164: 217222.

Oros M., Scholz T., Hanzelová V., Mackiewicz J.S. 2010: Scolex morphology of monozoic cestodes (Caryophyllidea) from the Palaeartic Region: a useful tool for species identification. Folia Parasitol. 57: 37-46.

Orosová M., Králová-Hromadová I., Bazsalovicsová E., ŠPAKULOVÁ M. 2010: Karyotype, chromosomal characteristics of multiple rDNA clusters and intragenomic variability of ribosomal ITS2 in Caryophyllaeides fennica (Cestoda). Parasitol. Int. 59: 351-357.

Pallas P.S. 1781: Bemerkungen ueber die Bandwürmer in Menchen und Thieren. N. Nord Beytr. Phys. Georg. Erd. Völkerbeschr. 1: 39-112.

Protasova E.P, Kuperman B.I., Roitman V.A., PoddubNAYA L.G. 1990: [Caryophyllid Tapeworms of the Fauna of the USSR.] Nauka, Moscow, 237 pp. (In Russian.) 
Ronquist F., Teslenko M., van der Mark P., Ayres D.L., Darling A., Höhna S., Larget B., Liu L., Suchard M.A., Huelsenbeck J.P. 2012: MrBayes 3.2: efficient Bayesian phylogenetic inference and model choice across a large model space. Syst. Biol. 61: 539-542.

Scholz T. 1989: Amphilinida and Cestoda, parasites of fish in Czechoslovakia. Acta. Sci. Nat. Brno 23: 1-56.

Scholz T., Brabec J., Králová-Hromadová I., Oros M., Bazsalovicsová E., Ermolenko A., Hanzelová V. 2011: Revision of Khawia spp. (Cestoda: Caryophyllidea), parasites of cyprinid fish, including a key to their identification and molecular phylogeny. Folia Parasitol. 58: 197-223.

Telford M.J., Herniou E.A., Russell R.B., Littlewood D.T.J. 2000: Changes in mitochondrial genetic codes as phylogenetic characters: two examples from the flatworms. Proc. Nat. Acad. Sci. USA 97: 11359-11364.

Received 26 November 2013
Waeschenbach A., Webster B.L., Littlewood D.T.J. 2012: Adding resolution to ordinal level relationships of tapeworms (Platyhelminthes: Cestoda) with large fragments of mtDNA. Mol. Phylogenet. Evol. 63: 834-847.

Werle E., Schneider C., Renner M., Volker M., Fiehn W. 1994: Convenient singlestep, one tube purification of PCR products for direct sequencing. Nucl. Acids Res. 22: 4354-4355.

Xi B.-W., Oros M., Wang G.-T., Wu S.-G., Gao D., Nie P. 2009: Khawia saurogobii n. sp. (Cestoda: Caryophyllidea) from freshwater fish Saurogobio spp. (Cyprinidae) in China. J. Parasitol. 95: 965-970..

ZwiCKL D.J. 2006: Genetic algorithm approaches for the phylogenetic analysis of large biological sequence datasets under the maximum likelihood criterion. $\mathrm{PhD}$ dissertation, University of Texas at Austin, $125 \mathrm{pp}$.

Accepted 21 February 2014 